\title{
Satunarcus, a new late Cambrian trilobite genus from southernmost Thailand and a reevaluation of the subfamily Mansuyiinae Hupé, 1955
}

\author{
Shelly J. Wernette, ${ }^{1} \odot$ Nigel C. Hughes, ${ }^{1,2} \odot$ Paul M. Myrow, ${ }^{3}$ and Apsorn Sardsud ${ }^{4}$ \\ ${ }^{1}$ Department of Earth and Planetary Sciences, University of California, Riverside, CA 92521, USA, <swern001@ucr.edu>, <nigel.hughes@ \\ ucr.edu> \\ ${ }^{2}$ Geological Studies Unit, Indian Statistical Institute, Kolkata, 700108, India \\ ${ }^{3}$ Department of Geology, Colorado College, Colorado Springs, CO 80903, USA <pmyrow@ColoradoCollege.edu> \\ ${ }^{4}$ Department of Mineral Resources, Rama VI Rd., Ratchathewee, Bangkok 10400, Thailand, <apsornsa@yahoo.com>
}

\begin{abstract}
The Ao Mo Lae Formation of the Tarutao Group crops out on Thailand's Tarutao Island and contains a diverse assemblage of late Furongian trilobite taxa, including several endemic forms. This study presents a new genus and species, Satunarcus molaensis, discovered at two locations on the island. A cladistic analysis of the kaolishaniid subfamily Mansuyiinae in light of Satunarcus and similar genera known from across upper Cambrian equatorial Gondwanan rocks suggests that the subfamily is polyphyletic in its current definition, and thus is not a natural group. Separating Mansuyia Sun, 1924 from the other taxa conventionally placed in Mansuyiinae permits recognition of a previously unrecognized monophyletic subfamily Ceronocarinae new subfamily. As established herein, this kaolishaniid subfamily contains Satunarcus n. gen. and all genera previously recognized as Mansuyiinae. with the exception of Mansuyia itself. Ceronocarinae n. subfam. occur in middle Jiangshanian to middle Cambrian Stage 10 sedimentary rocks from Australia, South China, North China, and Sibumasu, with most genera endemic to Australia.
\end{abstract}

UUID: http://zoobank.org/618c5136-73f0-4912-a7d3-e56559d2a76c

\section{Introduction}

Peninsular Thailand's latest Cambrian strata comprise interbedded fossiliferous sandstones and rhyolitic ash beds, making this succession particularly important for resolving the geochronology of the Cambro-Ordovician boundary (Stait et al., 1984). Previous studies of Thailand's Cambrian trilobites (Kobayashi, 1957; Shergold et al., 1988) recovered a mix of taxa both endemic to Thailand and shared with Australia, North China, or South China. Here we show that more taxa remain to be discovered and identified that help further resolve the biostratigraphic succession of Thailand and its paleogeographic association with other Gondwanan terranes. Satunarcus molaensis n. gen. n. sp. is one such new taxon. Satunarcus n. gen. belongs to Kaolishaniidae (Kobayashi, 1935) and, while morphologically distinctive, bears close resemblance to genera known from Australia, North China, and South China.

Trilobites of the corynexochid suborder Leiostegiina, particularly tsinaniids and kaolishaniids, are prevalent in the late Cambrian (Furongian) record from equatorial Gondwana. They occur in Sibumasu, South and North China, Bhutan, and Australia (Sun, 1924; Shergold, 1972, 1975, 1991; Shergold et al., 1988; Zhu et al., 2010, 2013; Hughes et al., 2011; Park et al., 2014). The evolution and dispersal patterns of Kaolishaniidae Kobayashi (1935) and Tsnianiidae Kobayashi (1933) reflect Cambro-Ordovician paleogeography during the final accretion of Gondwana prior to its mid-Paleozoic breakup
(Cawood et al., 2007). These trilobites are also useful index taxa for establishing Stage 10 biozones, including the Shergoldia nomas Zone of Australia and the Ptychaspis-Tsinania and Kaolishania pustulosa Zones of North China (Geyer and Shergold, 2000). The discovery of a new kaolishaniid genus, Satunarcus, from Thailand's Tarutao Group and its affinities with various genera traditionally classified as Mansuyiinae Hupé (1955) prompts a revision of this subfamily and its role in the evolution of Tsinaniidae from Kaolishaniidae.

Tsinaniids have been scrutinized in numerous studies on the origins of higher-level taxa that became prominent during the Great Ordovician Biodiversification Event. They have alternatively been suggested as a sister taxon to Asaphida (Zhu et al., 2007) or as an early family in, or sister taxon to, the derived corynexochid suborder, Illaenina (Fortey, 1997; Adrain, 2011). The asaphid hypothesis has been strongly refuted (Park and Choi, 2009; Zhu et al., 2010), while the basal illaenid hypothesis is not well supported, although classification schemes listing Tsinaniidae as an illaenid remain current (Adrain, 2011). As a result of investigations into the potential role of Tsinaniidae as a sister taxon to more derived Ordovician groups, several different cladistics-based phylogenetic schemes have arisen for the emergence of Tsinaniidae, with the general consensus being that the family is rooted in Kaolishaniidae (Zhu et al., 2013; Lei and Liu, 2014; Park et al., 2014). In each of these phylogenies, Mansuyia Sun, 1924 is important in the split between Tsinaniidae and other kaolishaniids. In one cladistic analysis, Mansuyia resolved 
as a paraphyletic stem genus to Tsinaniidae (Park et al., 2014), with the holaspid retention of pygidial spines linking it to Kaolishaniidae and the ventral median suture and overall pygidial form excluding the spines linking it to Tsinaniidae. In another analysis, Mansuyia was made the outgroup to tsinaniids, thus providing no meaningful information on the relationship between Kaolishaniidae and Tsinaniidae, while assuming a polarization of characters from Mansuyia to Tsinaniidae (Zhu et al., 2013). In yet a third study, the relationship among Kaolishania Kobayshi, 1935, Mansuyia, and tsinaniids was an unresolved polytomy (Lei and Liu, 2014).

All three cladistic investigations into the tsinaniidkaolishaniid link suffer from a lack of focus on the kaolishaniid taxa. Park et al. (2014) and Lei and Liu (2014) each used only a single kaolishaniid species apart from Mansuyia in the analysis; in Park et al. (2014), it is the outgroup, forcing a Mansuyia-Tsinaniidae connection. Additionally, no members of the taxa assumed to be Mansuyia's closest relatives, the Mansuyiinae Hupé, 1955, were included in any analysis. When considering the position of Mansuyia in regards to kaolishaniids and tsinaniids, the placement of taxa generally considered Mansuyia's closest relatives, the other Mansuyiinae, must be considered. Mansuyiinae is vaguely characterized as "Mansuyia-like taxa" (Shergold, 1972). Because Manusyia is the type genus of Mansuyiinae, any questions of its affinity should also consider the affinities of the entire subfamily.

The discovery of a new kaolishaniid trilobite from the Ao Mo Lae Formation of the Tarutao Group of southernmost peninsular Thailand prompts a reevaluation of kaolishaniid and tsinaniid systematics, with emphasis on the inclusion of a broader range of Mansuyiinae genera. The most similar previously published material comes from Australia and was originally assigned to Mansuyia cf. orientalis due to its comparable pygidium (Shergold, 1975, 1991), but for both the Thai and Australian material Mansuyia cf. orientalis is an unsatisfactory designation. Specimens from both collections are more similar to Mansuyiinae genera other than Mansuyia itself, particularly in the large, flat preglabellar area. The cladistic analysis described herein was initially conducted to evaluate the generic placement of the Thai and Australian material, but it reveals new insight into kaolishaniid-Mansuyia-tsinaniid evolution by restricting Mansusyiinae as it is currently understood and revealing a previously unrecognized clade within Kaolishaniidae.

\section{Geologic and stratigraphic context}

Western Thailand, along with northern Malaysia, eastern Myanmar, and western Yunnan, China, is part of the peri-Gondwanan terrane known as Sibumasu (Metcalfe, 2002) or the Shan-Thai block (Bunopas, 1982). To date, the island Ko Tarutao (Fig. 1) has the best-studied Cambrian fossils from Sibumasu (Kobayashi, 1957; Stait et al., 1984; Shergold et al., 1988); they are found in the Tarutao Group (Javanaphet, 1969), a clastic unit dominated by sandstone that forms the base of the Paleozoic succession in western Thailand. The Tarutao Group contains a diverse latest Cambrian and earliest Ordovician faunal assemblage, including the newly discovered Satunarcus molaensis n. gen. n. sp. Its best exposed and accessible outcrops are on Ko Tarutao itself, Thailand's southern-most island, which is

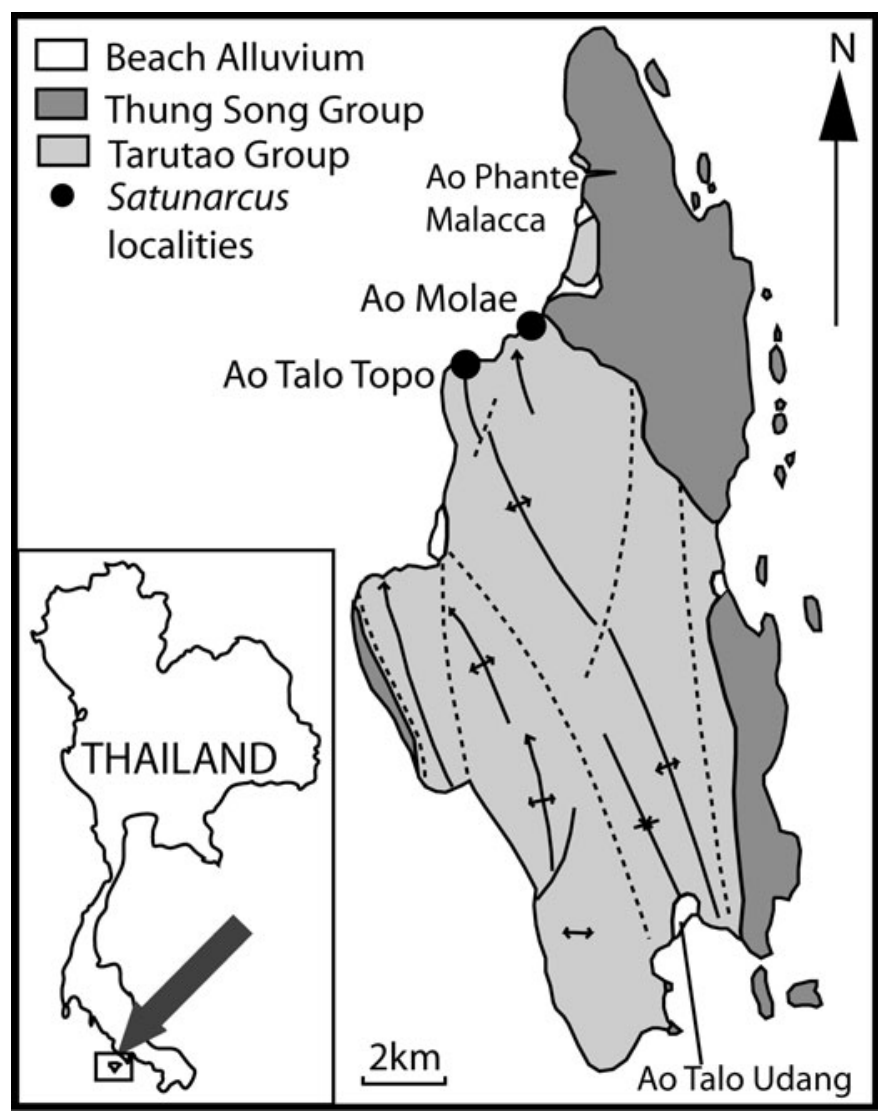

Figure 1. Geologic map of Ko Tarutao, Thailand with localities from which Satunarcus n. gen. was discovered (Modified from Shergold et al., 1988).

$\sim 25 \mathrm{~km}$ off the west coast of Satun province and $\sim 5 \mathrm{~km}$ north of Langkawi, Malaysia. There are some outcrops of the Tarutao Group on the mainland, but these are mainly quartzite, having experienced low-grade regional or contact metamorphism (Wongwanich et al., 2002); no fossils have been found outside of Ko Tarutao. The Machinchang Formation of Langkawi is the southern lithologic continuation of the Tarutao Group and does bear some fossils (Lee, 1983).

The Tarutao Group extends from the upper Furongian into the Tremadocian, where it transitions into the limestone of the Thung Song Group (Bunopas, 1982; Stait et al., 1984). The exact thickness of the Tarutao Group is difficult to estimate due to faulting; exposures occur only as isolated coastal headland outcrops in short sections separated by long covered intervals. Total thickness estimates range from $800 \mathrm{~m}$ (Bunopas et al., 1983) to 3,100 $\mathrm{m}$ (Teraoka et al., 1982). Shergold et al. (1988) accepted a conservative view of $850 \mathrm{~m}$, which we consider more reasonable than estimates surpassing $1,000 \mathrm{~m}$. At present, we have collected Cambrian fossils from four localities: Ao Phante Malaca, Ao Molae, Ao Talo Topo, and Ao Talo Udang. Satunarcus $\mathrm{n}$. gen. has been found only at Ao Molae $\left(06^{\circ} 40^{\prime} 13.68^{\prime \prime} \mathrm{N}, \quad 099^{\circ} 38^{\prime} 1.38^{\prime \prime} \mathrm{E}\right)$ and Ao Talo Topo $\left(06^{\circ} 40^{\prime} 8^{\prime \prime} \mathrm{N}, 099^{\circ} 37^{\prime} 6.12^{\prime \prime} \mathrm{E}\right)$, where it occurs in association with another genus first described from Ko Tarutao, the dikelocephalid Thailandium Kobayashi, 1957. The fossil assemblages at these two localities suggest that they are from near the base of Cambrian Stage 10, and equivalent in age to the Changia 
trilobite zone of North China (Sun, 1924; Zhou and Zhen, 2008; Peng, 2009) and the Sinosaukia impages through Shergoldia nomas zones of Australia (Fig. 2), 489 Ma (Shergold, 1972). The outcrops at Ao Talo Toppo and Ao Molae are from the Ao Mo Lae Formation, the stratigraphically lowest fossiliferous part of the Tarutao Group (Imsamut and Yathakam, 2011).

All specimens from Ao Talo Topo described herein were collected from a single horizon during our scouting expedition in 2008. Unfortunately a later excursion, during which the section was measured, failed to find Satunarcus n. gen. at Ao Talo Topo, although numerous other species were found. Without the recovery of at least some of the key species that co-occur with Satunarcus n. gen., such as Thailandium and Pagodia, it is not possible to place Satunarcus n. gen. within the section. The first fossils ever published from Ko Tarutao were from a lithologically and biostratigraphically comparable horizon though in a different section (Kobayashi, 1957; Shergold et al., 1988). Specimens from Ao Molae (horizons 1 and 2) were also collected at the time of the expedition to Ao Talo Topo, in addition to during a later visit in December 2016. Ao Molae has an $\sim 11 \mathrm{~m}$ thick section through the Ao Mo Lae Formation, with fossiliferous beds confined to the middle part (Fig. 3). Satunarcus molaensis n. gen. n. sp. itself has been recovered from only the upper half of the fossiliferous beds (4.71-6.01 m) of the Ao Molae section. When Ao Talo Topo and Ao Molae collections are considered together, S. molaensis n. gen. n. sp. co-exists with Eosaukia buravasi Kobayashi, 1957, Thailandium solum Kobayashi, 1957, Quadraticephalus planulatus (Kobayashi, 1957), Hoytaspis? thanisi Shergold et al., 1988, and Lichengia? tarutaoensis (Kobayashi, 1957). It is the recovery of Eosaukia, Thailandium, and Quadraticephalus that suggests stratigraphic equivalency with the Sinosaukia impages and Changia zones of Australia and North China, respectively.

The Tarutao Group is primarily composed of hummocky, cross-bedded and parallel-bedded, fine-grained quartzarenite with a minor component of siltstone and shale, and is interbedded with rhyolitic volcanic ash and breccia (Fig. 3). Fossils are primarily in coquina horizons within the sandstone beds (Fig. 4). Fossiliferous horizons are readily identifiable in cross section in the outcrop as thin $(<1 \mathrm{~cm})$, pitted horizons oriented parallel to bedding, from which internal and external molds can be retrieved. All Satunarcus n. gen. were recovered from such horizons, but a small number of other fossils, including trilobites, brachiopods, and cephalopods, are isolated within the sandstone and oriented obliquely to bedding. All fossils within the Tarutao Group are disarticulated, with the degree of fragmentation ranging from absent to unidentifiable scleritic hash. The molds forming the coquina horizons at Ao Talo Topo and Ao Molae are in some cases whitened by secondary silica precipitation that partially infill the mold. Preservation as molds in fine-grained sandstone precludes the occurrence of early ontogenetic stages, and only disarticulated holaspid sclerites

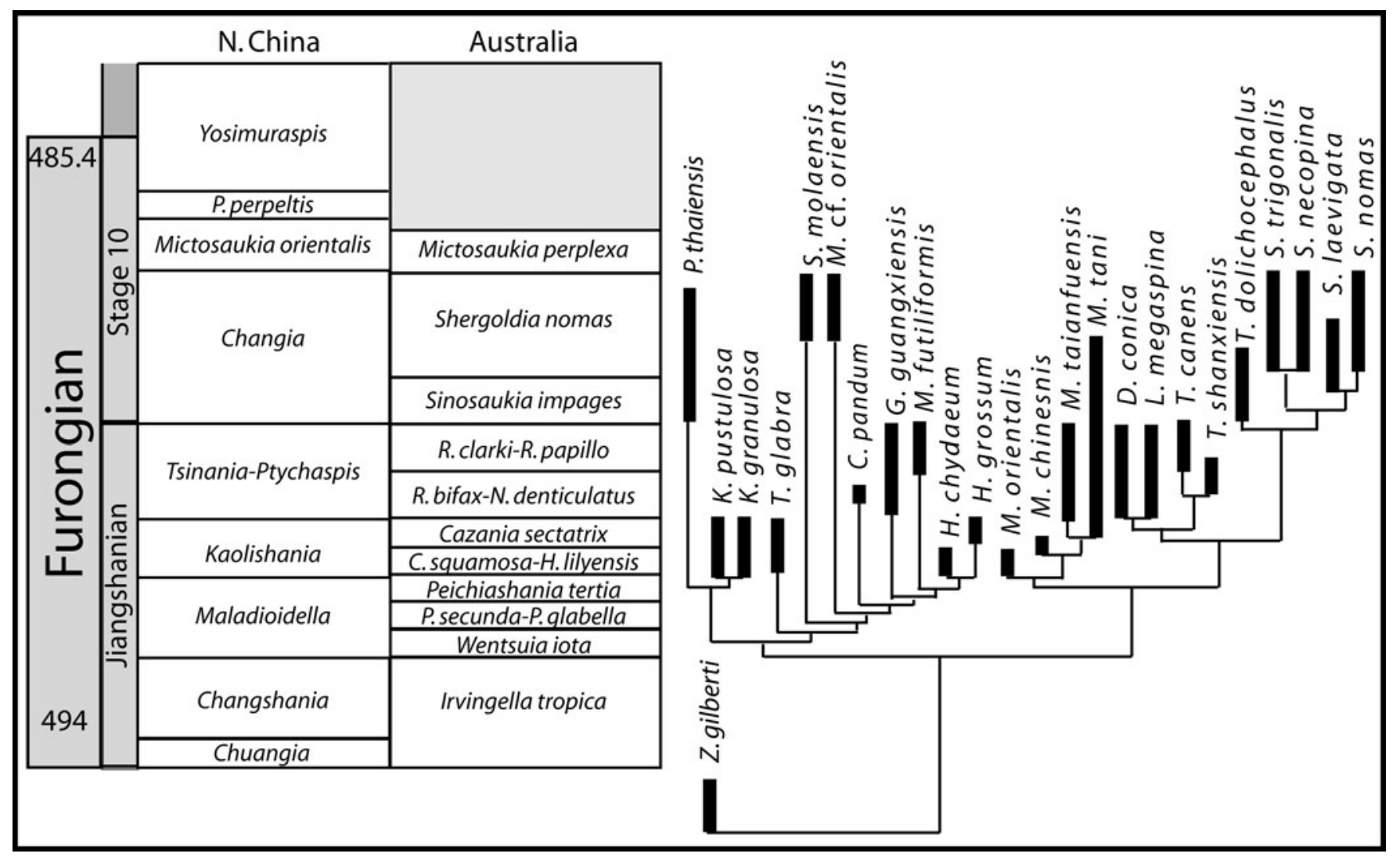

Figure 2. Trilobite biostratigraphic zones of North China and Australia and stratigraphic constraint of the tsinaniid and kaolishaniid cladogram. The taxa with abbreviated generic names are Pseudokoldinioidia perpeltis, Rhaptagnostus clarki, Rhaptagnostus papillo, Rhaptagnostus bifax, Neagnostus denticulatus, Caznaia squamosa, Hapsidocare lilyensis, Peichiashania secunda, and Prochuangia glabella (Shergold, 1972, 1975, 1991; Geyer and Shergold, 2000; Shergold et al., 2007; Zhu et al., 2007; Peng et al., 2009; Zhu et al., 2010, 2013; Hughes et al., 2011; Park et al., 2012, 2014; Lei and Liu, 2014). 


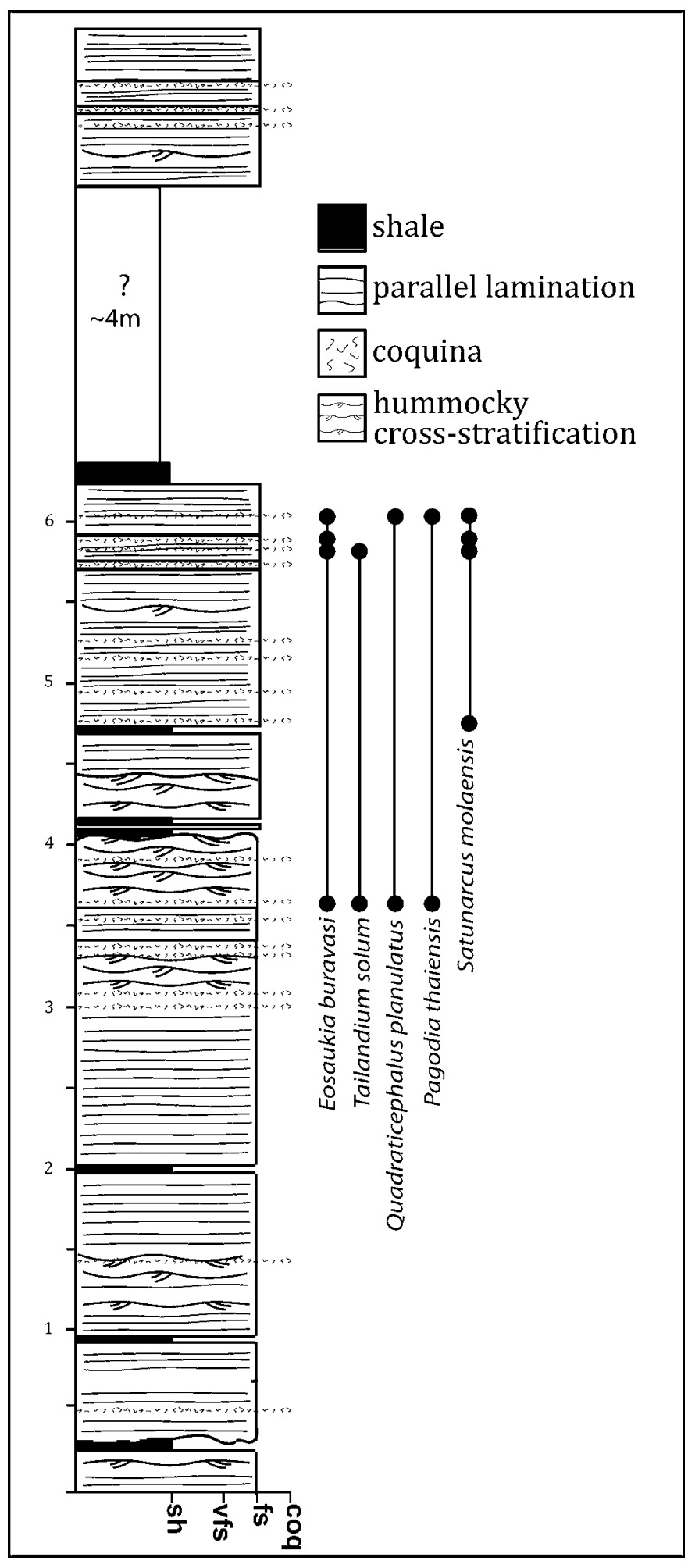

Figure 3. Ao Molae measured section and range chart. Section height is measured in meters.

have been recovered. For Satunarcus n. gen., pygidial and cranidial associations can be made with reasonable confidence on the basis of size, frequency of occurrence, and inferred taxonomic affinity, but no librigena, hypostomes, or thoracic segments have been found of the right size and morphology to

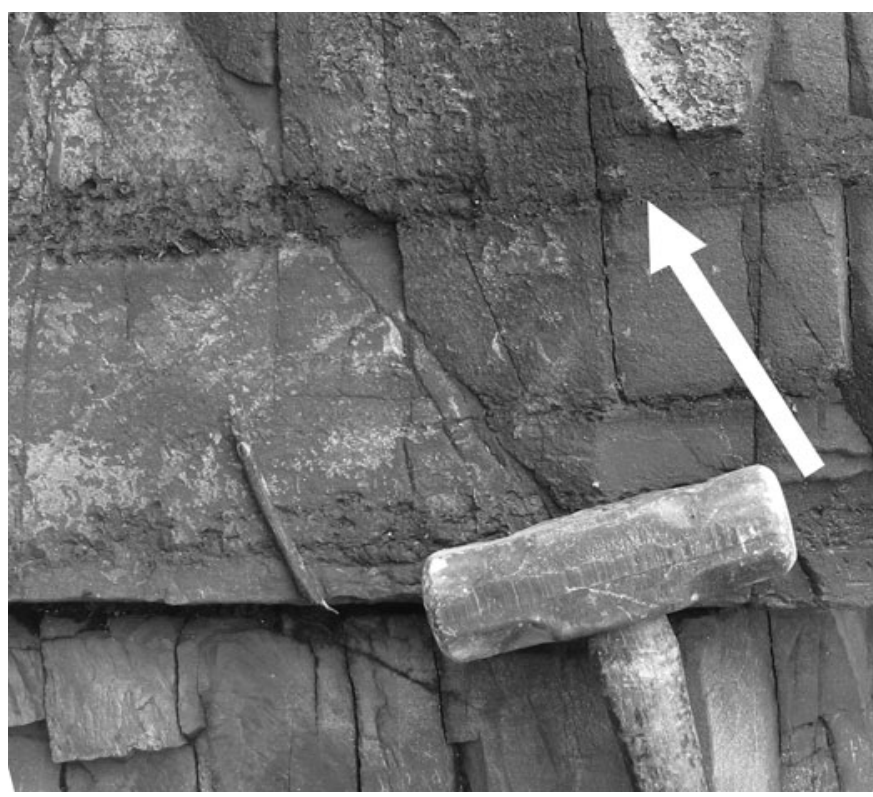

Figure 4. Photo of Ao Talo Topo bedding; the white arrow points to a pitted, fossiliferous shellbed horizon. Hammer included for scale.

make them a plausible match. This study's cladistic analysis is restricted to characters of mature holaspid cranidia and pygidia because this is the only information available for most tsinaniid and kaolishaniid taxa, including Saturnarcus n. gen.

\section{Characters and taxa used in cladistic analysis}

The cladistic analysis of Tsinaniidae and Kaolishaniidae presented herein use a heuristic examination of 51 characters, with a total of 91 character states, across 24 ingroup taxa and one outgroup (Table 1). The ingroup taxa were chosen based on the following criteria: (1) taxonomic significance of species-type species such as Mansuyia orientalis Sun, 1924 and Tsinania canens (Walcott, 1905) were favored because their characteristics are central to evaluating their generic concepts; (2) use in recent tsinaniid phylogenetic studies (including Zhu et al., 2013; Lei and Liu, 2014; Park et al., 2014)—taxa used in these studies were favored in order to facilitate comparisons between the results of these different phylogenetic analyses; (3) quality of published figures - analysis was based primarily on figured specimens, and those with only low resolution or poor-quality images from older publications are less useful in providing confident character-state assignments; and (4) taxonomic breadth of coverage-we favored sampling a wide range of genera from within Mansuyiinae more than multiple species within a single genus. Exceptions were made for Shergoldia and Tsinania because the monophyly of these genera is particularly questionable.

Previous analyses of Kaolishaniidae and Tsinaniidae used Kaolishania granulosa Kobayashi, 1933, Kaolishania pustulosa Sun, 1924, or Mansuyia orientalis Sun, 1924 as outgroups, all of which belong to either Kaolishaniidae or Tsinaniidae (Zhu et al., 2013; Lei and Liu, 2014; Park et al., 2014). However, in order to evaluate the relationship between kaolishaniids and tsinaniids, it is important to use an outgroup that is not a member of 


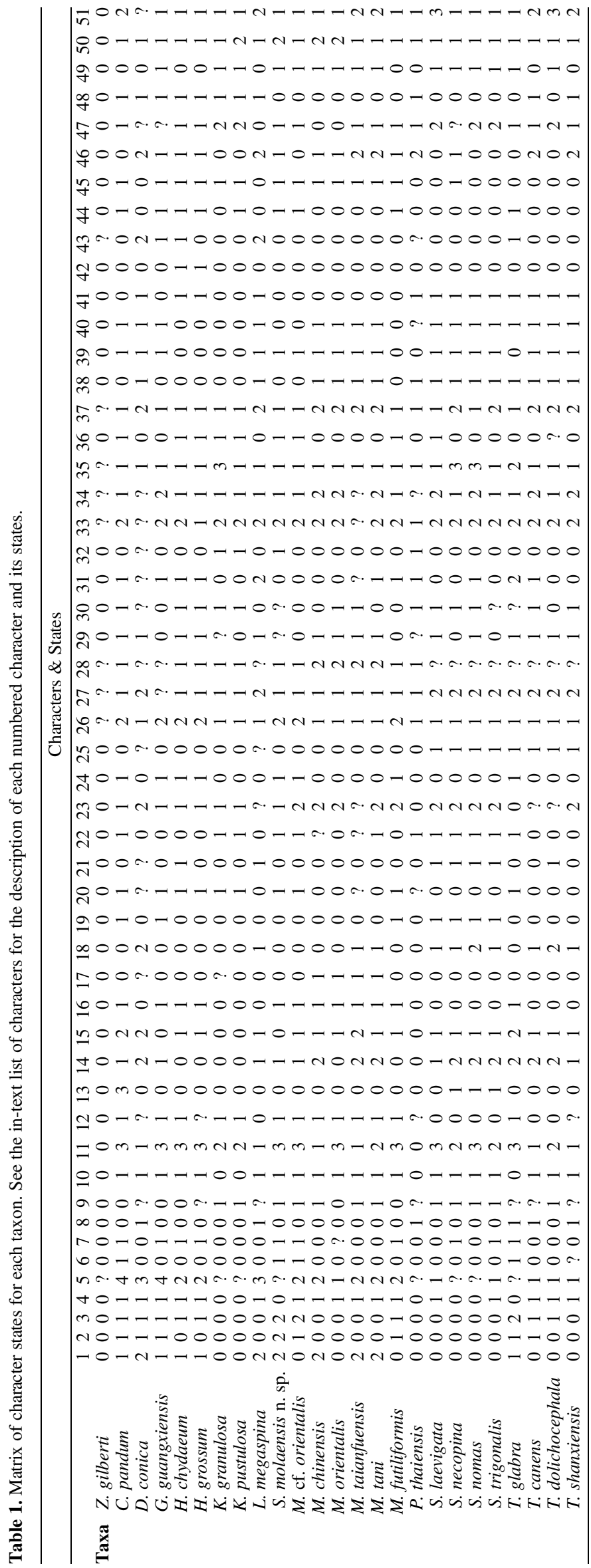

either. Because the relationships between kaolishaniids and tsinaniids may have implications for the derivation of Illaeniina from Leiostegiina, we chose to use an outgroup from the third Corynexochida suborder, Corynexochina, which is stratigraphically older than either Illaeniina or Leiostegiina. Zacanthoides gilberti Young and Ludvigsen, 1989 is suitable as the outgroup because it is a well-known, stratigraphically older representative of Corynexochina.

Cladistic analysis used the following species. For measurements we used the noted specimens as they are relatively complete an unambiguous representatives of the species.

Zacanthoides gilberti Young and Ludvigsen, 1989.-Two cranidia and two pygidia (Young and Ludvigsen, 1989, pl. 6, figs. 12, 13, 16, pl. 7, fig. 2).

Ceronocare pandum Shergold, 1975.-Two cranidia and one pygidium (Shergold, 1975, pl. 43, figs. 1, 7, 8).

Dictyella conica Shergold, Laurie, and Shergold, 2007.-Two cranidia and two pygidia (Shergold et al., 2007, figs. 27.a, 27.c, 27.j, 27.o, 27.r).

Guangxiaspis guangxiensis Zhou in Zhou et al., 1977.-Two cranidia and two pygidia (Zhu et al., 2010, fig. 5.9, 5.10).

Hapsidocare chydaeum Shergold, 1975.-One cranidium and three pygidia (Shergold, 1975, pl. 40, fig. 1, pl. 41, figs. 1-3).

Hapsidocare grossum Shergold, 1975.-One cranidium and one pygidium (Shergold, 1975, pl. 42, figs. 1, 5).

Kaolishania granulosa Kobayashi, 1933.- Two cranidia and two pygidia (Kobayashi, 1960, pl. 20, figs. 11, 12; Park et al., 2012, fig. 8.a, 8.b, 8.y).

Kaolishania pustulosa Sun, 1924.-Three cranidia and three pygidia (Sun, 1924, pl. 3., fig. 8.a, 8.e; Lu et al., 1965, pl. 81, figs. 1, 4; Qian, 1994, pl. 27, figs. 5, 8).

Lonchopygella megaspina Zhou in Zhou et al., 1977.-Three cranidia and three pygidia (Zhou et al., 1977, pl. 55, figs. 11, 12; Zhu et al., 2013, figs. 2.22, 2.23, 3.30, 3.31).

Satunarcus molaensis n. gen. n. sp.-Nine cranidia and six pygidia (Figs. 9, 10).

Mansuyia chinensis (Endo, 1939).-Two cranidia and two pygidia (Park et al., 2014, fig. 3.B, 3.H, 3.L, 3.N).

Mansuyia orientalis Sun, 1924.-Three cranidia and two pygidia (Qian, 1994, pl. 32, figs. 5, 6, 11, pl. 33, figs. 1, 3).

Mansuyia cf. orientalis (Sun, 1924; sensu Shergold, 1975, 1991).-Four cranidia and two pygidia (Shergold, 1975, pl. 38, figs. 6, 7; 1991, pl. 2, figs. 2, 4-6).

Mansuyia taianfuensis (Endo, 1939).-Two cranidia and two pygidia (Endo, 1939, pl. 2, figs. 21, 22; Park et al., 2014, fig. 6.f, 6.h)

Mansuyia tani Sun, 1935.- Two cranidia and two pygidia (Park et al., 2014, fig. 5.b, 5.g, 5.1, 5.p).

Mansuyites futiliformis Shergold, 1972.-Two cranidia and two pygidia (Shergold, 1972, pl. 13, figs. 1, 6, pl. 14, figs. 1, 4)

Pagodia thaiensis Kobayashi, 1957.-Two cranidia and one pygidium (Kobayashi, 1957, pl. 4, figs. 5-7).

Shergoldia laevigata Zhu, Hughes, and Peng, 2007.-Three cranidia and two pygidia (Zhu et al., 2007, figs. 2.c, 2.f, 3.e).

Shergoldia necopina (Shergold, 1975).- Two cranidia and one pygidium (Shergold, 1975, pl. 48, figs. 2, 3, 5).

Shergoldia nomas (Shergold, 1975).- Two cranidia and two pygidia (Shergold, 1975, pl. 47, figs. 1-3, 5). 
Shergoldia trigonalis (Shergold, 1975).-One cranidium and two pygidia (Shergold, 1975, pl. 50, figs. 3, 7, 8).

Taipaikia glabra (Endo in Endo and Resser, 1937).- Two cranidia and two pygidia (Endo and Resser, 1937, pl. 69, fig. 21; Hughes et al., 2011, figs. 9.e, 9.g, 10.c).

Tsinania canens (Walcott, 1905).-Three cranidia and two pygidia (Park et al., 2014, fig. 7.a-7.c, 7.g, 7.j).

Tsinania dolichocephala (Kobayashi, 1933).-Three cranidia and two pygidia (Lei and Liu, 2014, figs. 6.a-6.c, 6.g, 6.h).

Tsinania shanxiensis (Zhang and Wang, 1985).- - Two cranidia and two pygidia (Lei and Liu, 2014, figs. 3.d, 3.f, 5.m, 5.o).

Fifty-one characters of holaspid cranidia and pygidia were considered and possess a mix of binary and multi-state attributes. All quantitative character states are based on discrete breaks in character distributions. Characters that could not be coded for a species because of missing data or inapplicable features were coded as missing, indicated by "?." Characters inapplicable to the outgroup do not have an assigned state zero, and are also indicated by "?" (as in Carlucci et al., 2010 and Wernette and Westrop, 2016). The characters and character states are given below.

1. Anterior border dorso-ventral convexity.-(0) Convex, (1) Concave, (2) Flat.

2. Anterior border furrow lateral condition (the appearance of the lateral part of the anterior border furrow).-(0) Distinct, (1) Faint, (2) Effaced.

3. Anterior border furrow medial condition (the appearance of the medial part of the anterior border furrow).-(0) Distinct, (1) Faint, (2) Effaced.

4. Anterior margin shape.-(0) Evenly curved, (1) Triangular.

5. Anterior margin angularity (the angularity of the triangularshaped anterior margin from character 4[1]).-(1) Roundish, (2) Blunt, (3) Sharp, (4) Concave.

6. Anterior border lateral corner position.-(0) Opposite preglabellar furrow, (1) Anterior to glabella.

7. Preglabellar field.-(0) Absent, (1) Present.

8. Preocular facial suture orientation.-(0) Divergent, (1) Convergent.

9. Extent of preocular facial suture deflection (only applicable for taxa with character $8[0])$. - $(0)>33^{\circ},(1)<33^{\circ}$.

10. Facial suture and anterior margin intersection.-(0) Lateral, (1) Axial (facial suture anterior branches fuse on dorsal surface).

11. Maximum anterior area width (tr.) divided by preoccipital glabellar length (sag.).-(0) <110\%, (1) $110-129 \%$, (2) $130-149 \%,(3) \geq 150 \%$.

12. Widest (tr.) point on preocular cranidium.-(0) On anterior border, (1) Posterior to anterior border.

13. Plectrum.-(0) Absent, (1) Present.

14. Preglabellar furrow expression.-(0) Incised, (1) Inflected (preglabellar border defined by a sharp change of slope), (2) Faint.

15. Axial furrow expression.-(0) Deep, (1) Shallow, (2) Effaced.

16. Lateral glabellar furrow expression.-(0) Distinct, (1) Faint, (2) Effaced.
17. Preglabellar and anterior border furrow confluence.-(0) Confluent, (1) Separate.

18. Preglabellar and axial furrow junction.-(0) Defined, (1) Continuous curve.

19. Axial furrow bacculae.-(0) Absent, (1) Present.

20. Median glabellar ridge.-(0) Present, (1) Absent.

21. Posterior glabellar narrowing (posterior end of L1 distinctly narrower [tr.] than anterior).-(0) Absent, (1) Present.

22. SO medial anterior bend.-(0) Present, (1) Absent.

23. LO width relative to L1.-(0) Same, (1) LO narrower, (2) LO wider.

24. LO termination at axial furrows.--(0) Pinched (LO shortens [exsag.] as it approaches the axial furrows), (1) Blunt (LO truncates against axial furrows).

25. Transverse postoccipital ridge (a flange or ridge on the posterior edge of the occipital ring).-(0) Absent, (1) Present (Fig. 5.1).

26. Anterior fixigenal termination (the feature against which fixigena terminate anteriorly).-(1) Anterior border (fixigena terminate against the anterior border furrow), (2) Preglabellar field (the preglabellar field separates the fixigena from the anterior border).

27. Adaxial position of fixigenal termination (the position of the adaxial end of the line denoting the anterior edge of the fixigena).-(1) Opposite glabella, (2) Anterior to glabella (Fig. 5.2).

28. Glabellar adaxial fixigenal termination (for taxa with character 27[1] the glabellar feature against which the anterior adaxial fixigenal corner terminates).-(1) Anterior glabellar corner, (2) Preglabellar border (Fig. 5.2).

29. Palpebral lobe curvature (how strongly curved the adaxial edge of the palpebral lobe is).-(0) Strong, (1) Weak.

30. Palpebral lobe curvature evenness.-(0) More curved posteriorly, (1) Evenly curved.

31. Exsagittal position of palpebral lobe anterior point.-(0) Anterior to S2, (1) Opposite S2, (2) Opposite L2.

32. Palpebral lobe posterior position.-(0) Posterior to S1, (1) Opposite S1.

33. Eye ridge.-(1) Absent, (2) Present.

34 . Eye ridge condition (only applies to taxa with character 33 [2]).-(1) Faint, (2) Distinct.

35. Postocular facial suture shape.-(1) Increasingly arched toward posterior, (2) Straight, (3) Increasingly arched abaxially (Fig. 5.3).

36. Cranidial posterior border shape.-(0) Nearly straight, (1) Distinctly curved.

37. Posterior border furrow length (exsag.).-(1) Consistent length, (2) Abaxially lengthening.

38. Anterior pygidial corner shape (the extent of rounding at the inflection where the anterior pygidial border joins the lateral pygidial border).-(0) Rounded, (1) Angular.

39. Anterior pygidial margin shape.-(0) Straight, (1) Arched posterolaterally.

40. Anteriormost pygidial segment length (exsag.).-(0) Distally expanding, (1) Constant.

41. Paired segment-related spines.-(0) Present, (1) Absent.

42. Paired pygidial border spines (pygidial spines extended from undifferentiated border rather than as extensions of segments).-(0) Absent, (1) Present. 


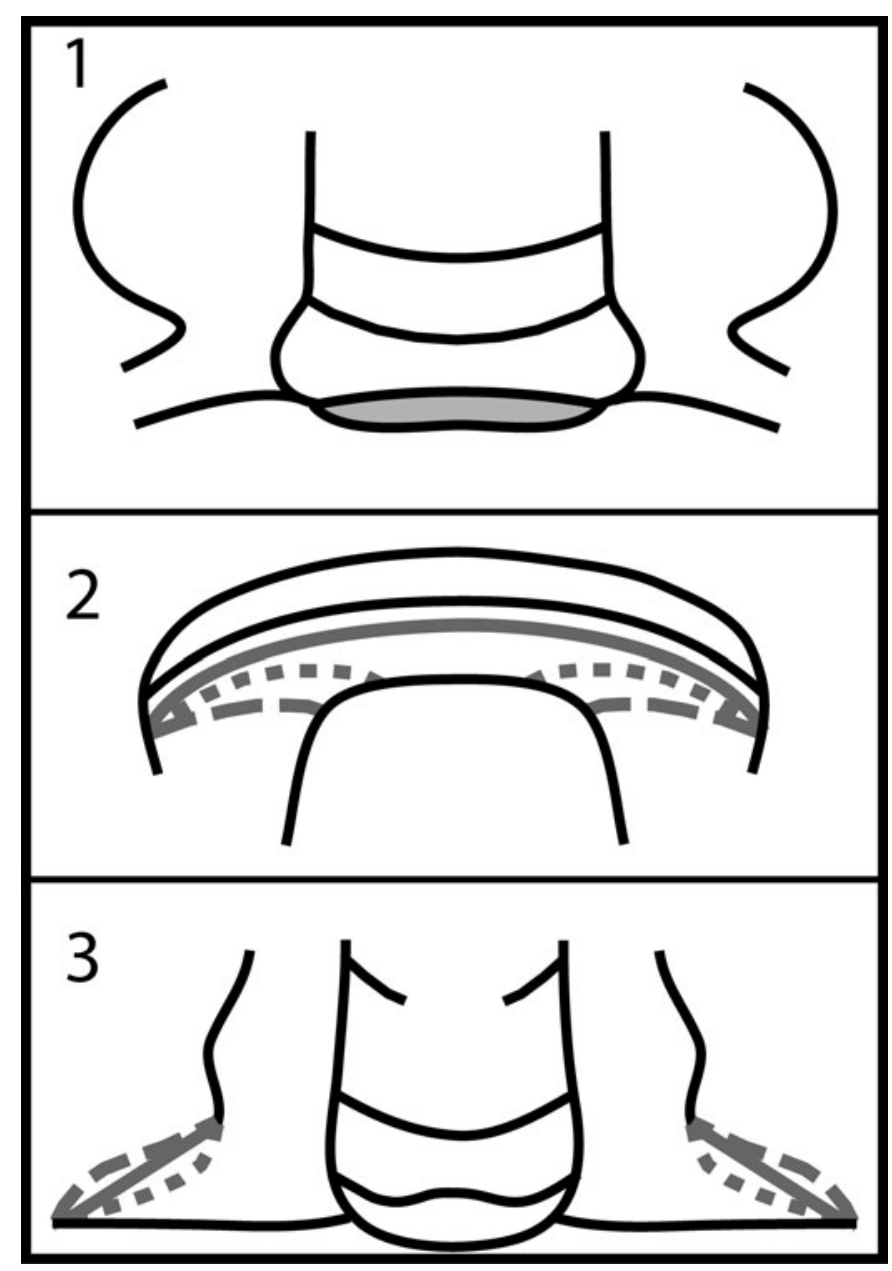

Figure 5. Explanatory illustrations of select characters: (1) post-occipital ridge 25[1]; (2) anterior termination position of inflated fixigenal areas: solid line 27 [2], short dash 28[2], long dash 28[1]; (3) post ocular facial suture shape: long dash 35[1], solid line 35[2], short dash 35[3].

43. Posterior pygidial margin shape--(0) Strongly curved, (1) Gently curved, (2) Triangular.

44. Pygidial axial furrow shape-_(0) Straight, (1) Curved.

45. Macropleural pygidial segment.-(0) Absent, (1) Present.

46. Pygidial border width (sag. and exsag.).-(0) Broad, (1) Narrow, (2) Absent.

47. Pleural bands.-(0) Continue to margin, (1) Fade out gradually before border, (2) Abrupt termination defining border.

48. Pygidial border convexity.-(0) Concave, (1) Convex.

49. Posterior axial termination point.-(0) Pygidial margin, (1) Before pygidial margin.

50. Axial ring shape--(0) Medial posterior inflection, (1) Straight, (2) Medial anterior inflection.

51. Number of pygidial rings.-(0) Four, (1) Five to Seven, (2) Eight to Nine, (3) 10 or more.

\section{Results of Cladistic Analysis}

We utilized Mesquite (Maddison, 2001) to build the matrix, Tree Analysis Using New Technology (TNT; Goloboff et al., 2008) to run the analysis, and Winclada (Nixon, 2002) to map characters and evaluate some support metrics. The heuristic analysis of the matrix of 25 taxa by 51 characters described above used Wagner trees with 100 random seeds and 1000 replications, saving up to 10 trees per replication. The analysis resulted in a single most-parsimonious tree with length 187, CI 37, and RI 67 (Fig. 6). The general structure of the cladogram is two sided and generally follows the currently recognized systematics; kaolishaniids, including Satunarcus n. gen., are on one side and tsinaniids on the other. Exceptions to the traditional classification scheme are that Mansuyia Sun, 1924, generally accepted to be a kaolishaniid (Shergold, 1972), shows affinity with the tsinaniids, and Taipaikia Kobayashi, 1960, generally accepted to be a tsinaniid (Kobayashi, 1960; Hughes et al., 2011), groups with the kaolishaniids. The unambiguous character supporting the grouping of Mansuyia with Tsinaniidae is 11[1] (a preglabellar width that is 110-129\% of the glabellar length) (Fig. 7). Character 17[1] (the presence of axial and preglabellar furrows that are smoothly continuous and undifferentiated), with the support of four additional ambiguous characters, supports Mansuyia as its own clade rooting at the base of Tsinaniidae with a Bremer index of four (Fig. 6.1). Tsinania is revealed to be a polyphyletic concept, its members forming a clade only with the inclusion of Shergoldia, Dictyella, and Lonchopygella. No unambiguous characters support the monophyly of Shergoldia, but its basal node has a Bremer support of three. Dictyella and Lonchopygella also fall within the clade encompassing Tsinania and Shergoldia. The node joining Dictyella and Lonchopygella is unambiguously supported by 5[3] (a distinctly angular convexly triangular anterior margin) and 43[2] (a sharply triangular pygidium).

Taipaikia's grouping within Kaolishaniidae, as opposed to Tsinaniidae, is as part of the clade containing Satunarcus n. gen. and the genera formerly assigned to Mansuyiinae, excluding Mansuyia. This clade is supported by three unambiguous characters and a Bremer support index of five. The supporting unambiguous characters include a medially effaced anterior border furrow (3[2]), an anterior border entirely anterior to the glabella, as opposed to the anterior border's lateral corners extending back to opposite or posterior the anterior glabellar margin (6 [1]), and an occipital lobe that truncates bluntly at the axial furrows rather than laterally pinching out (24[1]). Within this clade, an even tighter, similarly supported clade exists that includes Satunarcus n. gen., Mansuyites, Ceronocare, Guangxiaspis, Hapsidocare, and Mansuyia cf. orientalis. This clade is unambiguously supported by the fixigena anteriorly terminating against the broad preglabellar field as opposed to the anterior borders, 26[2]. The node joining the group has a Bremer support index of five.

\section{Materials and methods}

The specimens were prepared manually using a Dremel tool, blackened with India ink, whitened with ammonium chloride, and photographed with a Leica stereoscopic camera model MZ16. Apart from Satunarcus molaensis n. gen. n. sp. itself, the systematic analysis was based exclusively on figures from prior publications. The criteria used in the selection of species for analysis and which specimens were used for measurements are listed in the "Characters and taxa used in 


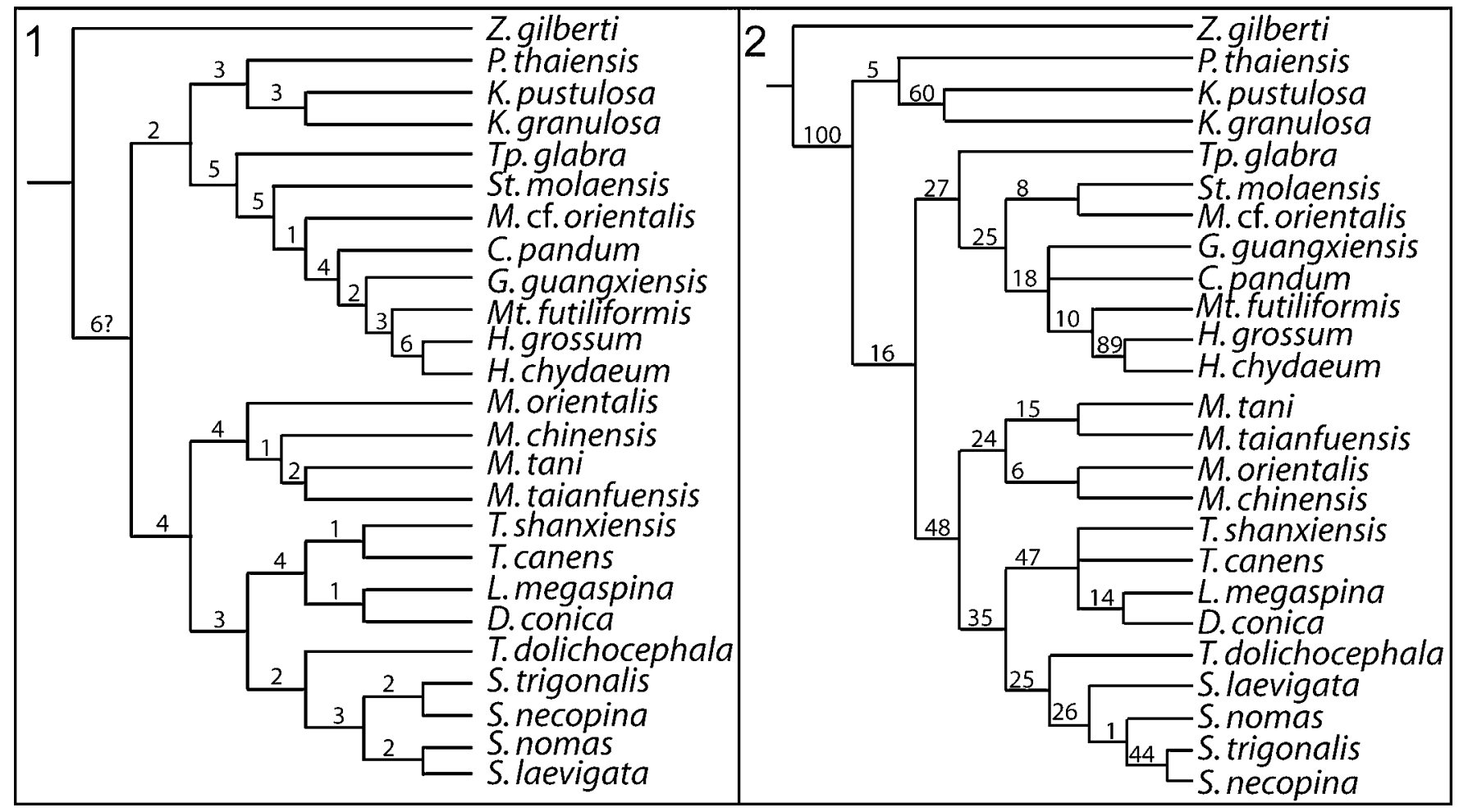

Figure 6. (1) Bremer support for the most parsimonious tree, tree length 187; (2) Bootstrap results from 10000 replicates; numbers are given as percentages. To avoid confusion for genera starting with the same letter, the following scheme is applied: $\mathrm{M}=$ Mansuyia $; \mathrm{Mt}=$ Mansuyites; $\mathrm{S}=$ Shergoldia $; \mathrm{St}=$ Satunarcus $\mathrm{n}$. gen.; $\mathrm{Tp}=$ Taipaikia $; \mathrm{T}=$ Tsinania .

cladistic analysis" section above. All figures and plates were created using Adobe Photoshop CC2017 and Adobe Illustrator CS2.

Repositories and institutional abbreviations.-All Satunarcus molaensis $\mathrm{n}$. gen. n. sp. illustrated in this paper are reposited in Thailand's Department of Mineral Resources' Geological Referenced Sample Collection (DGSC); unfigured specimens are reposited in either DGSC or the Cincinnati Museum Center (CMC).

\section{Systematic paleontology}

The systematic paleontology section is authored by Wernette and Hughes.

Class Trilobita Walch, 1771

Order Corynexochida Kobayashi, 1935

Suborder Leiostegiina Bradley, 1925

Superfamily Leiostegioidea Bradley, 1925

Family Kaolishaniidae Kobayashi, 1935

Subfamily Ceronocarinae new subfamily

Type genus._Ceronocare Shergold, 1975.

Type species.—Ceroncare pandum Shergold, 1975.

Diagnosis.-Ceronocarinae n. subfam. cranidium is distinguished by a long (sag.) frontal area comprising a depressed or flat elongated (sag.) preglabellar field with comparatively short (sag.) anterior border; a broad (tr.) frontal area that reaches maximum width on the anterior border; anterior border with lateral corners anterior to the preglabellar margin; prepalpebrally divergent anterior facial sutures that converge anteriorly to meet medially or are nearly convergent at the anterior cranidial margin; inflated palpebral areas that anteriorly terminate with a moderately strong to sharp inflection point opposite the preglabellar furrow and are separated from the anterior border by a wide (tr. \& exsag.) preglabellar field; occipital ring that does not laterally narrow or pinch out at the axial furrows. Pygidia possess one pair of segmentally derived spines and an inflated posterior band on the anterior pygidial segment.

Remarks.-Ceronocarinae n. subfam. encompasses genera previously contained in Mansuyiinae, with the exception of Mansuyia Sun, 1924. Shergold (1972) restricted Mansuyiinae to include only "Mansuyia-like" genera. However, the cladistic analysis herein reveals that these "Mansuyia-like" genera are not closely related to Mansuyia, rendering this conception of the subfamily polyphyletic and obsolete. Ceronocare Shergold, 1975, Mansuyites Shergold, 1972, Guangxiaspis Zhou in Zhou et al., 1977, and Hapsidocare Shergold, 1975 are no longer assigned to Mansuyiinae, and are hereby reassigned to Ceronocarinae n. subfam., which includes Satunarcus n. gen. This subfamily encompasses those taxa that have a particularly long preglabellar field and inflated palpebral areas anteriorly defined by a sharp inflection point (Fig. 6). Ceronocare displays the most exaggerated form of these characters. It is evident that the preglabellar field is lengthened here, not the anterior border, 


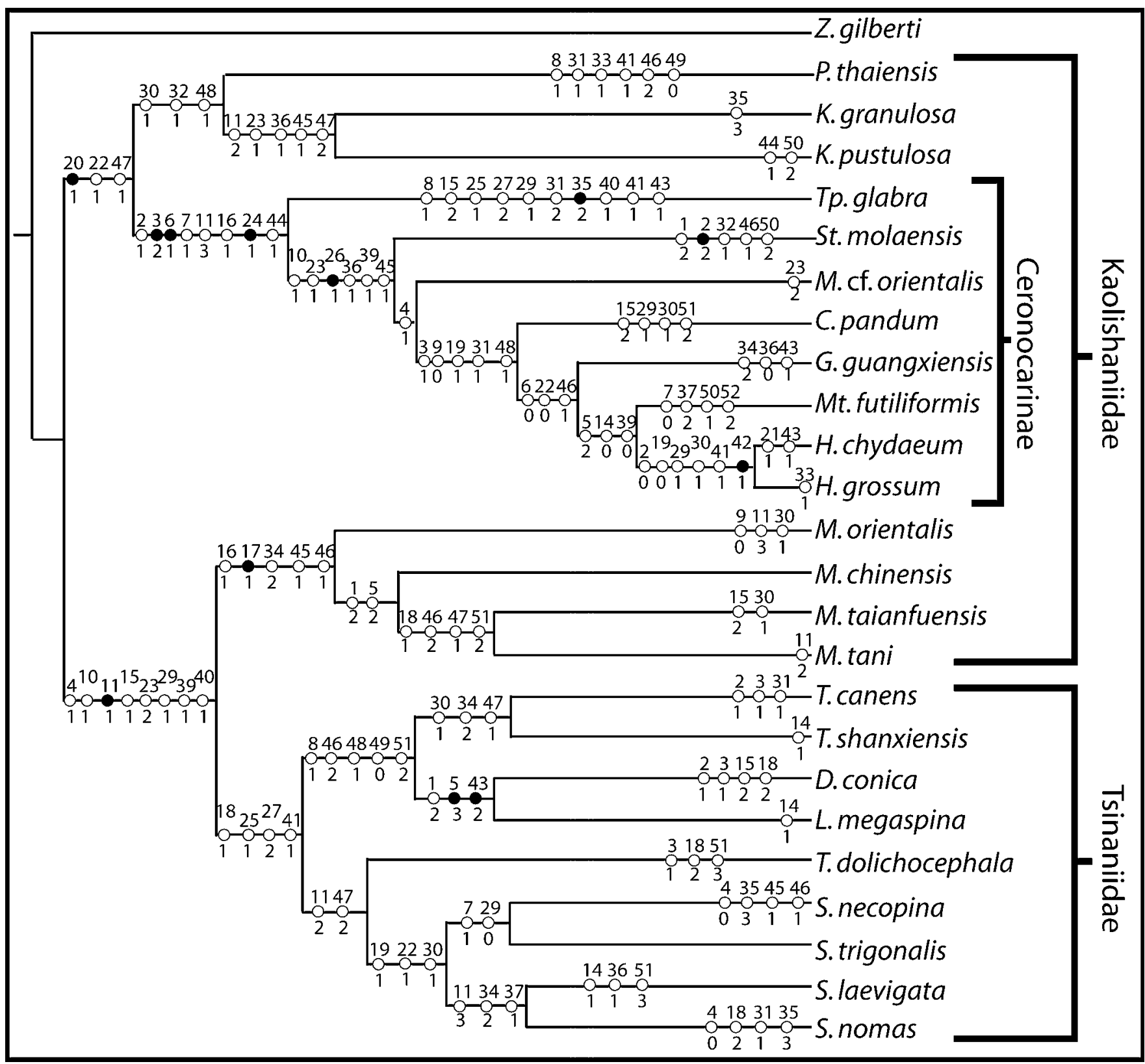

Figure 7. Character optimization for the most parsimonious tree. Numbers on top show the character number and numbers on bottom show the state for that character. Filled circles indicate those characters that are unambiguous. To avoid confusion for genera starting with the same letter, the following scheme is applied: $\mathrm{M}=$ Mansuyia $; \mathrm{Mt}=$ Mansuyites $; \mathrm{S}=$ Shergoldia $; \mathrm{St}=$ Satunarcus $\mathrm{n}$. gen.; $\mathrm{Tp}=$ Taipaikia $; \mathrm{T}=$ Tsinania .

because an anterior border is visible in some genera, including Satunarcus n. gen., Ceronocare, and Hapsidocare. Homologous depressions in the preglabellar area occur in Tsinania and Mansuyia as a merger between the anterior border and preglabellar furrows, but the condition is much more exaggerated in Ceronocarinae. Ceronocarinae n. subfam. are most diverse in Australia, but also present in South China and Sibumasu. Ceronocare was chosen as the type genus because it best exemplifies the strongly inflated palpebral areas terminating sharply into a long, broad preglabellar field with a very short anterior border whose furrow is medially effaced.

Genus Satunarcus new genus
Type species.—Satunarcus molaensis n. gen. n. sp.; by original designation; by monotypy.

Diagnosis.-As for the type species by monotypy.

Occurrence.-Ao Mo Lae Formation of the Tarutao Group of Ko Tarutao, Thailand. Furongian, Cambrian Stage 10, stratigraphically near the boundary between the Sinosaukia impages and Shergoldia nomas trilobite zones of Australia. Ao Talo Topo horizon 1 and Ao Molae horizons $4.71 \mathrm{~m}, 5.81$ $\mathrm{m}, 5.84 \mathrm{~m}$, and $6.01 \mathrm{~m}$.

Etymology._ "Satun-" is in honor of Satun UNESCO Global Geopark where the type species is found; "-arcus" is in 
recognition of the particularly arched posterolateral projections, an unusual feature useful in distinguishing this genus.

Remarks.-Satunarcus n. gen. is a member of Ceronocarinae n. subfam. that may have split from the rest of the subfamily early in its development (Fig. 2). Its general dimensions in terms of preglabellar area and glabellar width and length are similar to Mansuyia cf. orientalis, particularly to specimens from Australia's Pacoota Sandstone, which are preserved under similar lithologic and taxonomic conditions (Shergold, 1991). Nevertheless, M. cf. orientalis is excluded from Satunarcus on account of its long, strongly curved palpebral lobes and narrow, weakly curving posterolateral projections.

\section{Satunarcus molaensis new species}

Figures 8-10

Holotype.-DGSC F0343, Figures 9.1-9.3; Ao Mo Lae Formation of the Tarutao Group; Furongian, Cambrian Stage 10; Ao Molae bed $5.81 \mathrm{~m}$. Paratypes: DGSC F0358, F0351, F0356, F0337, Figures 9.8-9.11, 10.3, 10.5, 10.6.

Diagnosis.-Cranidium with long, broad, flat or slightly concave frontal area dominated by preglabellar field with indistinguishable or poorly differentiated anterior border; hourglass-shaped glabella relatively narrow (tr.) and short (sag.); palpebral lobes short (exsag.), weakly curved; palpebral areas anteriorly terminate at broad preglabellar field; posterolateral projections broad and strongly posteriorly arched. Pygidium with broad, semielliptical outline; five axial rings; axis terminating bluntly at posterior border; posterior border narrows medially.

Occurrence.-Ko Tarutao, Thailand at localities Ao Talo Topo, undetermined horizon, and Ao Molae horizons $4.71 \mathrm{~m}, 5.81 \mathrm{~m}$, $5.84 \mathrm{~m}$, and $6.01 \mathrm{~m}$; Ao Mo Lae Formation, Tarutao Group; Furongian, Cambrian Stage 10.

Description.-Glabellar width at L1 35-40\% cranidial width across palpebral areas; total glabellar length $55-60 \%$ of total cranidial length; anterior margin strongly curved; anterior border poorly differentiated to effaced; preglabellar area long (sag. and exsag.) and flat to slightly concave; preglabellar area maximum width 270-300\% L1 glabellar width; anterior suture branches diverge $\sim 15-20^{\circ}$; glabella hourglass shape with rounded anterior margin; preglabellar furrow laterally deep and medially shallowing to effaced; glabella narrowest across L2; three pairs of short (tr.), firmly incised lateral glabellar furrows angled obliquely toward posterior; S1 broadens (exsag.) abaxially; axial furrows weakly incised; S3 very short, nearly effaced; SO deep, but slightly shallowing medially; LO short (sag.) and constant length (sag. and exsag.) across width (tr.); LO forms continuous band with posterior cranidial border, but differentiated from rest of border by distinct axial furrows; LO width (tr.) slightly less than L1 width; palpebral areas moderately inflated, terminating anteriorly at preglabellar field with moderately sharp inflection; palpebral lobes narrow (tr.), straight, and short (exsag.), 30-35\% glabellar

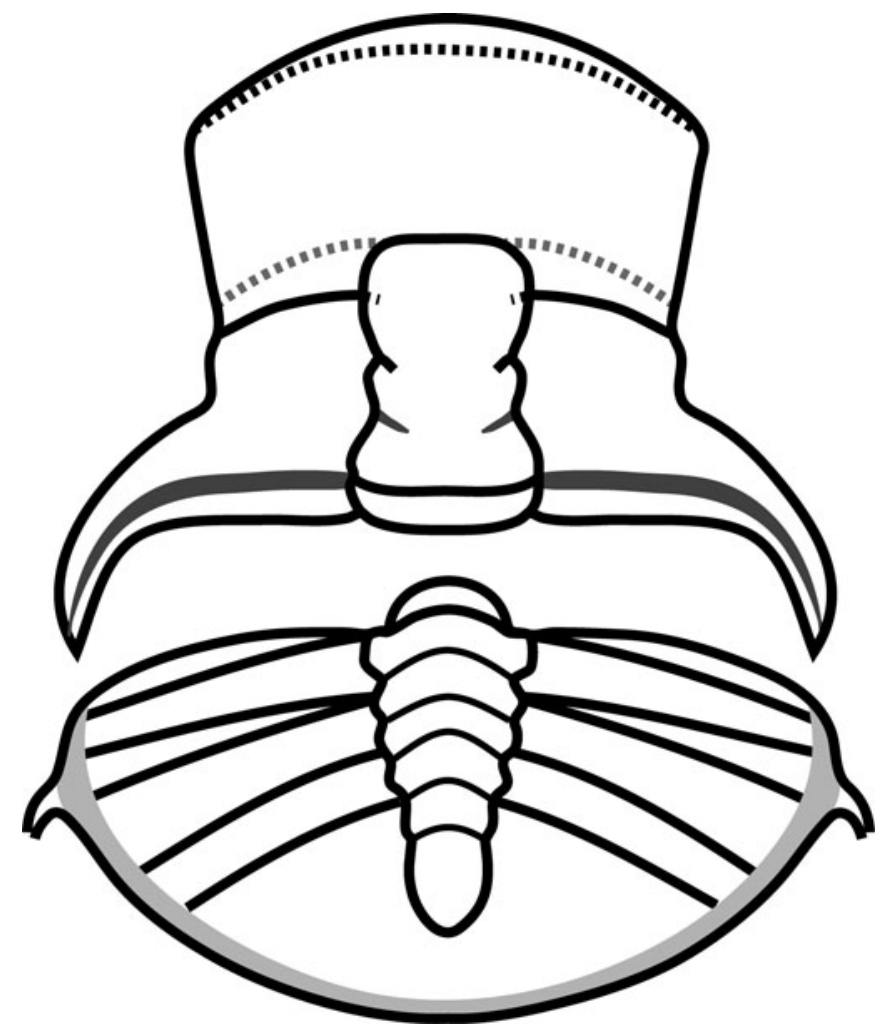

Figure 8. Line drawing of Satunarcus molaensis n. gen., n. sp. Gray region on pygidium represents the concave posterior border. Dotted line on preglabellar field is the often-effaced anterior border furrow.

length; palpebral lobes angled $10-15^{\circ}$ from sagittal axis, anteriorly palpebral lobe connected to $\mathrm{S} 3$ by short (exsag.) eye ridge; posterolateral projection broad (tr.) and long (exsag.), forming a curving triangular shape; posterolateral projection curves $\sim 90^{\circ}$ of arc, approaching resupinate condition; posterior border curves evenly parallel to posterior margin with broad (exsag.), firmly incised posterior border furrow.

Pygidial width (tr.) $\sim 175 \%$ of length (sag.); anterior margin gently curved and medially straight (tr.); posterior margin smoothly and strongly curved but for posterolateral spines; axial length $75-85 \%$ of pygidial length, terminating at evenly sloped posterior border; anterior axial width $\sim 25 \%$ of maximum pygidial width; axial furrows straight, at $10-15^{\circ}$ angle to sagittal axis; five axial segments, excluding terminal piece; axial ring furrows weakly incised and medially arched anteriorly; pleural furrows straight and nearly effaced; posterior band of anterior segment gently expanded; other pleural bands subequal; furrows become obsolete abruptly defining pygidial border; pygidial border narrow (tr., sag.), 15-20\% of anterior pygidial width; border narrows sagittally, almost pinching out; one pair of lateral spines apparently related to the posterior band of the first pygidial segment; spine short and thin (tr., exsag., and dorsoventrally) and rarely preserved.

Etymology.-Named for the holotype locality Ao Molae and for the Ao Mo Lae Formation, the only geologic unit currently known with this species. 

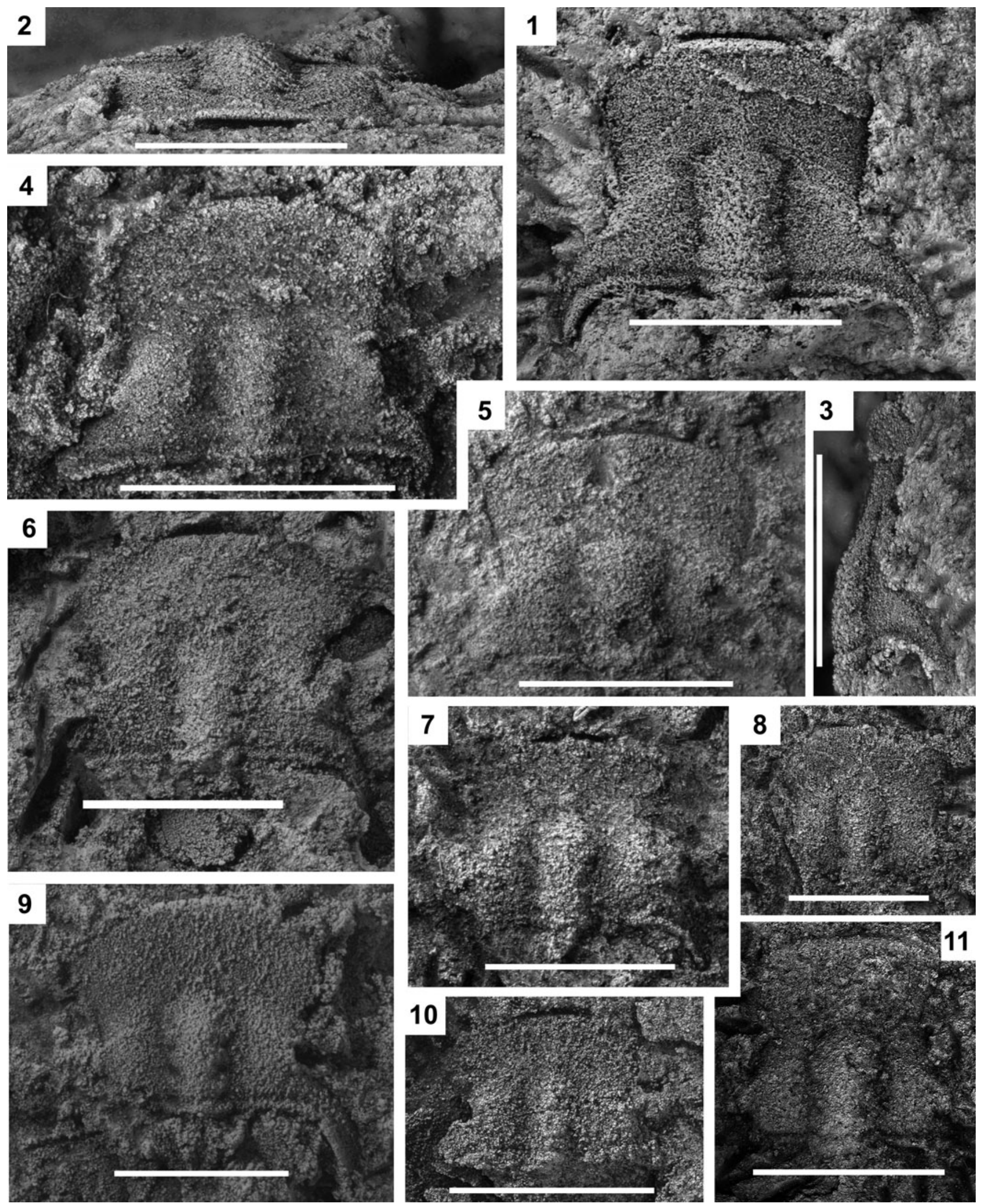

Figure 9. Satunarcus molaensis n. gen., n. sp., all cranidia. (1-3) Holotype: dorsal, anterior, and right lateral views, respectively, DGSC F0343, Ao Molae horizon $5.81 \mathrm{~m}$; (4) DGSC F0371, Ao Talo Topo; (5) DGSC F0383, Ao Talo Topo; (6) DGSC F0333, Ao Molae horizon $4.71 \mathrm{~m}$; (7) DGSC F0363, Ao Molae horizon 5.84 m; (8) DGSC F0358, Ao Molae horizon 5.81 m; (9) DGSC F0351, Ao Molae horizon 5.81 m; (10) DGSC F0356, Ao Molae horizon 5.81 m; (11) DGSC F0337, Ao Molae horizon $5.81 \mathrm{~m}$. Scale bars are $5 \mathrm{~mm}$. 

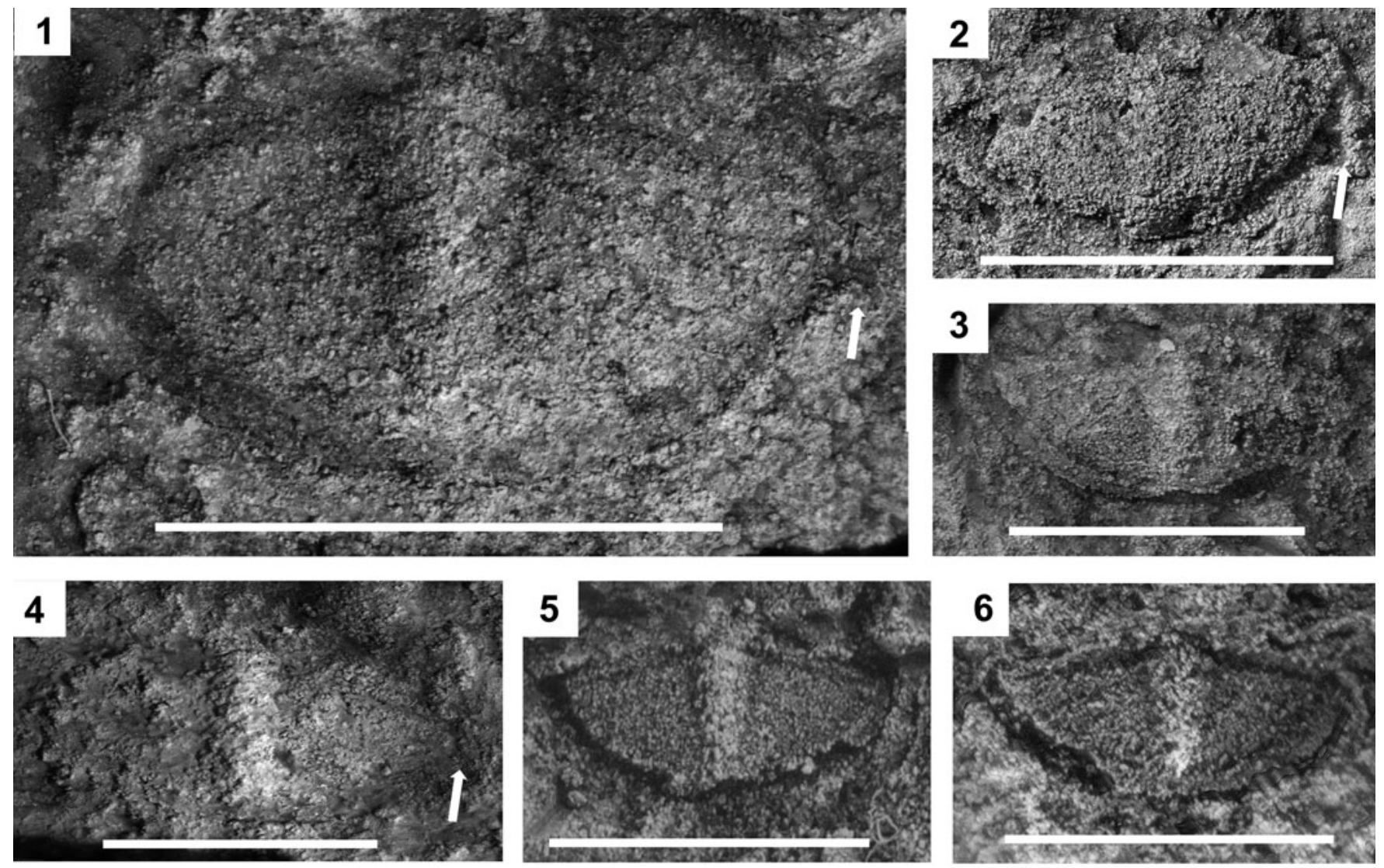

Figure 10. Satunarcus molaensis n. gen., n. sp., all pygidia. (1) DGSC F0381, Ao Talo Topo; (2) DGSC F0382, Ao Talo Topo; (3) DGSC F0341, Ao Molae horizon $5.81 \mathrm{~m}$; (4) DGSC F0384, Ao Talo Topo; (5) DGSC F0360, Ao Molae horizon $5.81 \mathrm{~m}$; (6) DGSC F0359, Ao Molae horizon $5.81 \mathrm{~m}$. Arrows point to spine bases. Scale bars are $2.5 \mathrm{~mm}$.

Materials.-Cranidia: From Ao Molae horizon $4.71 \mathrm{~m}$, one figured (DGSC F0333); from Ao Molae horizon $5.81 \mathrm{~m}$, five figured and two unfigured (DGSC F0337, F0343, F0351, F0352, F0356, F0358; CMC IP83136); from Ao Molae horizon $5.84 \mathrm{~m}$, one figured (DGSC F0363); from Ao Molae horizon $6.01 \mathrm{~m}$, two unfigured (CMC IP83154, IP83160); from Ao Molae horizon 2, one unfigured (CMC IP83165); from Ao Talo Topo, two figured and three unfigured (DGSC F0371, F0372, F0383, F0385, F0386). Pygidia: from Ao Molae horizon $5.81 \mathrm{~m}$, three figured and 11 unfigured (DGSC F0341, F0344; F0353, F0359, F0360, F0361; CMC IP83129, IP83130, IP83135, IP83137-IP83139, IP83141, IP83142); from Ao Molae horizon $5.84 \mathrm{~m}$, three unfigured (CMC IP83143-83145); from Ao Molae horizon $6.01 \mathrm{~m}$, two unfigured (CMC IP83153, IP83161); from Ao Talo Topo, three figured and three unfigured (DGSC F0373, F0374, F0381, F0382, F0384, F0387). All specimens are internal molds preserved in fine-grained sandstone, except IP83136, which is an external mold in sandstone.

Remarks._Satunarcus molaensis n. gen. n. sp.is a small species with cranidia rarely exceeding $5 \mathrm{~mm}$ in length. While ornamentation is easily distinguishable on both the cranidium and pygidium of Mansuyia cf. orientalis in its distinctive palpebral and posterolateral regions, in $S$. molaensis n. gen. n. sp. it is unknown due to their small size, sandstone preservation, and scarcity of external molds. The spines on the pygidium are exceptionally poorly preserved; they are typically preserved only as outward extensions of the impression left from the border in an otherwise smoothly rounded pygidial margin. Confidence that this is a spine rather than irregularity in the matrix comes from the marginal disruption consistently occurring in the same position on multiple specimens. Satunarcus molaensis n. gen. n. sp. is found at two separate but geographically close localities with similar lithofacies. At Ao Molae, where the stratigraphy is better known and fossils more broadly sampled, S. molaensis n. gen. n. sp. is stratigraphically restricted to a range of $<1 \mathrm{~m}$, which may explain why it has not been recovered in previous analyses of the Tarutao fauna (Kobayashi, 1957; Shergold et al., 1988). Where it does occur, S. molaensis n. gen. n. sp. is moderately abundant.

\section{Discussion}

This is the first phylogenetic analysis of tsinaniids and kaolishaniids to include a variety of taxa from both groups. Previous studies, which were constrained in taxon diversity due to the inclusion of ontogenetic data, have used kaolishaniids only as an outgroup for evaluating the tsinaniids (Zhu et al., 2013) or included only a single supposed kaolishaniid genus, Mansuyia, to consider the relationship with tsinaniids (Lei and Liu, 2014; 
Park et al., 2014). The results herein indicate that if Mansuyia were excluded from Kaolishaniidae and reclassified as a tsinaniid, then Kaolishaniidae forms its own clade separate from Tsinaniidae. If Mansuyia is a member of Kaolishaniidae, then this family is paraphyletic with Tsinaniidae emerging out of it. Because the nature of evolution inherently results in paraphyletic groupings, there is no reason to reassign Mansuyia based on these results. Mansuyia itself is a well-supported clade, contrary to Park et al.'s (2014) view of Mansuyia as a stem group to the Tsinaniidae. The other genera previously assigned to Mansuyiinae, excluding Mansuyia, form their own well-supported clade, herein designated Ceronocarinae n. subfam., within the Kaolishaniidae. Because a polyphyletic taxon is incompatible with evolution-based taxonomy, Mansuyiinae is henceforth restricted to the genus Mansuyia. The Ceronocarinae n. subfam. are characterized by a long (sag.) and broad (tr.) frontal area consisting of an extended and nearly flat preglabellar field and short anterior border, prepalpebrally divergent anterior sutures that converge anteriorly to meet medially, inflated palpebral areas that terminate with a moderately strong to sharp inflection point opposite the preglabellar furrow, and a pygidium possessing one pair of segmentally derived spines and an inflated posterior band on the anterior pygidial segment.

Taipaikia has historically been included with Tsinaniidae, which are generally characterized as large, effaced trilobites (Kobayashi, 1960; Jell and Adrain, 2002). However, this classification has previously been challenged by Taipaikia's abaxial intersection between the facial suture sand the anterior margin (Zhu et al., 2007; Hughes et al., 2011). Zhu et al. (2013) presented a cladistic scheme that supports the classification of Taipaikia as a tsinaniid more closely related to Tsinania and Shergoldia than to Mansuyia, but that analysis did not test the relationship of Taipaikia to tsinaniids, because it assumed, a priori, Mansuyia as the outgroup. This forced the tree to be rooted on Mansuyia with Taipaikia ingroup to Tsinaniidae. The more comprehensive view of Kaolishaniidae provided herein resolves Taipaikia as part of Ceronocarinae n. subfam., and as a kaolishaniid rather than as a tsinaniid (Figs. 6, 7).

Based on the phylogenetic analysis presented here, it is clear that Mansuyia cf. orientalis sensu Shergold (1975) is not a member of Mansuyia, and is not closely comparable to Mansuyia orientalis. As part of Ceronocarinae n. subfam., its generic affiliation should be reevaluated following a comprehensive revision of the available material.

\section{Conclusions}

Satunarcus molaensis is a new species and genus from Ko Tarutao, Thailand. It belongs within the new subfamily Ceronocarinae, erected herein, which contains many of the genera previously assigned to Mansuyiinae. Cladistic analysis of Mansuyiinae, "Mansuyia-like" genera, and related members of Kaolishaniidae and Tsinaniidae reveals that Mansuyia and other genera assigned to Mansuyiinae (Shergold, 1972) are polyphyletic, hence the restriction of the subfamily Mansuyiinae to Mansuyia alone. The subfamily Ceronocarinae n. subfam. is erected to contain the genera formerly considered Mansuyiinae, excluding Mansuyia itself.

Resolution of Tsinania and Shergoldia, the more derived tsinaniids, agrees with Park et al.'s (2014) and Zhu et al.'s (2013) conclusion that, as presently conceived, these genera are not monophyletic. In the previous two studies, Tsinania is nested within Shergoldia, and in this analysis the opposite is true. Given the lower stratigraphic position of Tsinania, the latter analysis is a more stratigraphically consistent branching relationship (Fig. 2). While no non-reversible characters support the monophyly of Shergoldia, reversible supporting characters include the presence of bacculae, an anteriorly directed medial bend in the occipital furrow, and a curved anterior pygidial margin. This analysis additionally agrees with Park et al.'s (2014) view that Lonchopygella is part of the Tsinania-Shergoldia clade, not a sister taxon as depicted in Zhu et al. (2013). Lonchopygella is most closely related to Dictyella based on the overall effaced and triangular pygidial and cranidial morphology.

\section{Acknowledgments}

Thank you to Colorado College undergraduate student, T. White, for digitizing the stratigraphic sections. T. Wongwanich, X. Zhu, S. Peng, and several additional staff from Thailand's Department of Mineral Resources helped to collect specimens on one or both of the Tarutao expeditions. We thank B. Lieberman as associate editor handling our paper and L. Amati and T.-Y. Park for their most helpful reviews. This study was funded by student grants from the Geological Society of America, the American Museum of Natural History (Lerner-Gray Memorial Fund), the Evolving Earth Foundation, the American Association of Petroleum Geologists (David Worthington Named Grant), and the Paleontological Society (Allison R. "Pete" Palmer Grant) and by the National Science Foundation grant EAR-1849963 to Hughes and EAR-1849968 to Myrow. Additional funding included NSF grants EAR-053868 and EAR-1124303 that supported contributions from Hughes and EAR-1124518 that supported contributions from Myrow. Hughes acknowledges receipt of Fulbright Academic and Professional Excellence Award 2019 APE-R/107 and thanks the Geological Studies Unit, Indian Statistical Institute, Kolkata for kindly hosting him. This research is a contribution towards IGCP 668: Equatorial Gondwanan History and Early Palaeozoic Evolutionary Dynamics.

\section{References}

Adrain, J.M., 2011, Class Trilobita Walch, 1771, in Zhang, Z.-Q., ed., Animal biodiversity: an outline of higher-level classification and survey of taxonomic richness: Zootaxa, v. 3148, p. 104-109.

Bradley, J.H., 1925, Trilobites of the Beekmantown in the Phillipsburg region of Quebec: Canadian Field Naturalist, v. 39, p. 5-9.

Bunopas, S., 1982, Paleogeographic history of western Thailand and adjacent parts of Southeast Asia-a plate tectonics interpretation: Thai Geological Survey, Paper 5, $810 \mathrm{p}$.

Bunopas, S., Muenlek, S., and Tansuwan, V., 1983, Geology of Tarutao Island: Journal of the Geological Society of Thailand, v. 6, p. 121-138.

Carlucci, J.R., Westrop, S.R., and Amati, L., 2010, Tetralichine trilobites from the Upper Ordovician of Oklahoma and Virginia and phylogenetic systematics of the Tetralichini: Journal of Paleontology, v. 84, p. 1099-1120.

Cawood, P.A., Johnson, M.R.W., and Nemchin, A.A., 2007, Early Palaeozoic orogenesis along the Indian margin of Gondwana: tectonic response to Gondwana assembly: Earth and Planetary Science Letters, v. 255, p. $70-84$. 
Endo, R., 1939, Cambrian fossils from Shantung, in Aoki, R., Jubilee Publication in Commemoration of Prof. H. Yabe's 60th Birthday: Sendai, Sasaki-Insatsu, p. 1-18.

Endo, R., and Resser, C.E., 1937, The Sinian and Cambrian formations and fossils of southern Manchoukuo: Manchurian Science Museum Bulletin, v. 1, p. 23-365.

Fortey, R.A., 1997, Classification, in Kaesler, R.L. ed., Treatise on Invertebrate Paleontology, Part O, Trilobita (revised): Boulder, Colorado and Lawrence, Kansas, Geological Society of America and University of Kansas, p. O289$\mathrm{O} 302$.

Geyer, G., and Shergold J., 2000, The quest for internationally recognized divisions of Cambrian time: Episodes, v. 23, p. 188-195.

Goloboff, P.A., Farris, J.S. and Nixon, K.C., 2008, TNT, a free program for phylogenetic analysis: Cladistics, v. 24, p. 774-786.

Hughes, N.C., Myrow, P.M., McKenzie, N.R., Harper, D.A.T., Bhargava, O.N. Tangri, S.K., Ghalley, K.S., and Fanning, C.M., 2011, Cambrian rocks and faunas of the Wachi La, Black Mountains, Bhutan: Geological Magazine, v. 148, p. $351-379$.

Hupé, P., 1955, A propos des organes de Pander des trilobites: Bulletin de la Société Géologique de France, v. 6, p. 701-711. [in French]

Imsamut, S., and Yathakam, W., 2011, Stratigraphic correlation of the TarutaoLangkawi, area, (Thai side): Report Bureau of Geological Survey, DMR, Bangkok, Thailand, p. 1-64.

Javanaphet, J.C., 1969, Geological map of Thailand, scale 1:1,000,000: Department of Mineral Resources, Bangkok, Thailand.

Jell, P.A., and Adrain, J.M., 2002, Available generic names for trilobites: Memoirs-Queensland Museum, v. 48, p. 331-552.

Kobayashi, T., 1933, Upper Cambrian of the Wuhutsui Basin, Liaotung, with special reference to the limit of the Chaumitien (or Upper Cambrian) of eastern Asia, and its subdivision: Japanese Journal of Geology and Geography, v. 11 , p. $55-155$.

Kobayashi, T., 1935, The Cambro-Ordovician formations and faunas of South Chosen. Palaeontology: The University of Tokyo, v. 4, p. 49-344.

Kobayashi, T., 1957, Upper Cambrian fossils from peninsular Thailand: Journal of the Faculty of Sciences University of Tokyo, v. 2, p. 367-382.

Kobayashi, T., 1960, Notes on the geologic history of Thailand and adjacent territories: Japanese Journal of Geology and Geography, v. 31, p. 129-148.

Lee, C.P., 1983, Stratigraphy of the Tarutao and Machinchang Formations: Proceedings of the Workshop on Stratigraphic Correlation of Thailand and Malaysia, technical papers, stratigraphic correlation of Thailand and Malaysia, Haad Yai Thailand, v. 1, p. 20-38.

Lei, Q.P. and Liu, Q., 2014, Late ontogeny of the trilobite Tsinania shanxiensis (Zhang and Wang, 1985) from the Cambrian (Furongian) of Anhui, China and its systematic implications: Palaeoworld, v. 23, p. 229-239.

Lu, Y.H., Chang, W.T., Chu, C.L., Chien, Y.Y., and Hisang, L.W., 1965, Trilobites of China: Beijing, Science Press, 766 p. [in Chinese]

Maddison, W.P., 2001, Mesquite: A Modular System for Eolutionary Analysis. Version 1.12.

Metcalfe, I., 2002, Permian tectonic framework and palaeogeography of SE Asia: Journal of Asian Earth Sciences, v. 20, no. 6, p. 551-566.

Nixon, K.C., 2002, WinClada, version 1.00. 08. Ithaca, Published by the author.

Park, T.Y., and Choi, D.K., 2009, Post-embryonic development of the Furongian (late Cambrian) trilobite Tsinania canens: implications for life mode and phylogeny: Evolution \& Development, v. 11, p. 441-455.

Park, T.Y., Sohn, J.W., and Choi, D.K., 2012, Middle Furongian (late Cambrian) polymerid trilobites from the upper part of the Sesong Formation, Taebaeksan Basin, Korea: Geosciences Journal, v. 16, p. 381-398.

Park, T.Y., Kim, J.E., Lee, S.B., and Choi, D.K., 2014, Mansuyia Sun, and Tsinania Walcott, from the Furongian of North China and the evolution of the trilobite family Tsinaniidae: Palaeontology, v. 57, p. 269-282.

Peng, S., 2009, The newly-developed Cambrian biostratigraphic succession and chronostratigraphic scheme for South China: Chinese Science Bulletin, v. 54, p. 4161-4170.

Peng, S.C., Hughes, N.C., Heim, N.A., Sell, B.K., Zhu, X.J., Myrow, P.M., and Parcha, S.K., 2009, Cambrian trilobites from the Parahio and Zanskar valleys, Indian Himalaya: Journal of Paleontology, v. 83, p. 1-95.
Qian, Y., 1994, Trilobites from the middle Upper Cambrian (Changshan Stage) of north and northeast China: Palaeontologica Sinica, New Series B, no. 30, p. 1-176. [in Chinese]

Shergold, J.H., 1972, Late Upper Cambrian trilobites from the Gola Beds, Western Queensland: Bureau of Mineral Resources, Australia, Bulletin 112, p. $1-126$.

Shergold, J.H., 1975, Late Cambrian and early Ordovician trilobites from the Burke River structural belt, western Queensland, Australia: Bureau of Mineral Resources, Australia, Bulletin 153, p. 1-251.

Shergold, J.H., 1991, The Pacoota Sandstone, Amadeus Basin, Northern Territory: stratigraphy and palaeontology: Bureau of Mineral Resources, Australia, Bulletin 237, p. 1-93.

Shergold, J.H., Burrett, C.F., Akerman, T., and Stait, B., 1988, Late Cambrian trilobites from Tarutao Island, Thailand: New Mexico Bureau of Mines and Mineral Resources, Memoir 44, p. 303-320.

Shergold, J.H., Laurie, J.R., and Shergold, J.E., 2007, Cambrian and Early Ordovician trilobite taxonomy and biostratigraphy, Bonaparte Basin, Western Australia: Memoirs of the Association of Australasian Palaeontologists, v. 34, p. $17-86$.

Stait, B., Burrett, C.F., and Wongwanich, T., 1984, Ordovician trilobites from the Tarutao Formation southern Thailand: Neues Jahrbuch fur Geologie und Palaeontologie Monatschefte, v. 1, p. 53-64.

Sun, Y.C., 1924, Contributions to the Cambrian faunas of North China: Palaeontologica Sinica, Series B, no. 1, p. 1-109.

Teraoka, Y., Sawata, H., Yoshida, T., and Pungrassami, T., 1982, Lower Paleozoic formations of the Tarutao Islands, Southern Thailand: Prince of Songkhla University, Geological Research Project Publication, v. 6, p. 1-54.

Walch, J.E.I., 1771, Die naturgeschichte der verteinergungen, Dritter Theil: Zur erläuterung der Knorrischen Sammlung von Merkwürdigkeiten der Natur: Nürnberg, P.J. Felstecker, 235 p.

Walcott, C.D., 1905, Cambrian faunas of China: Proceedings of the U.S. National Museum, v. 29, p. 1-106.

Wernette, S.J., and Westrop, S.R., 2016, The mid-Cambrian (Drumian; Marjuman) trilobites 'Athabaskiella' Kobayashi 1942 and 'Bathyuriscidella' Rasetti 1948 (Dolichometopidae) from Quebec and Newfoundland, eastern Canada: Australasian Palaeontological Memoirs, v. 49, p. 145-180.

Wongwanich, T., Tansathien, W., Leevongcharoen, S., Paengkaew, W., Thiamwong, P., Chaeroenmit, J., and Saengsrichan, W., 2002, The Lower Paleozoic Rocks of Thailand: The Symposium on Geology of Thailand, 26-31 August 2002, Bangkok, Thailand, p. 16-21.

Young, G.A., and Ludvigsen, R., 1989, Mid-Cambrian trilobites from the lowest part of the Cow Head Group, western Newfoundland: Geological Survey of Canada Bulletin, v. 392, p. 1-49.

Zhang, J.L., Wang, S.X., 1985, Trilobites, in Tianjin Institute of Geology and Mineral Resources, ed., Palaeontological Atlas of North China (1), Palaeozoic: Beijing, Geological Publishing House, p. 27-488. [in Chinese]

Zhou, T.M., Liu, Y.R., Meng, X.S., and Sun, Z.H., 1977, Trilobita: Palaeontological Atlas of Central and South China, v. 1, p. 104-266. [in Chinese]

Zhou, Z.Y., and Zhen, Y.Y., 2008, Trilobite Record of China: Beijing, Science Press, $401 \mathrm{p}$.

Zhu, X.J., Hughes, N.C., and Peng, S.C., 2007, On a new species of Shergoldia Zhang and Jell, 1987 (Trilobita), the family Tsinaniidae and the order Asaphida: Memoirs of the Association of Australasian Palaeontologists, v. 34, p. 243-253.

Zhu, X.J., Hughes, N.C., and Peng, S.C., 2010, Ventral structure and ontogeny of the late Furongian (Cambrian) trilobite Guangxiaspis guangxiensis Zhou, 1977 and the diphyletic origin of the median suture: Journal of Paleontology, v. 84, p. 493-504.

Zhu, X.J., Hughes, N.C., and Peng, S.C., 2013, Onset of maturity and ontogenetic tagmatization of the pygidium in the development of Lonchopygella megaspina (Trilobita, later Furongian, Cambrian): Journal of Paleontology, v. 87, p. $472-483$.

Accepted: 5 April 2020 